\title{
Analysis of ERCC1 and ERCC2 gene variants in osteosarcoma, colorectal and breast cancer
}

\author{
BENJAMÍN GÓMEZ-DÍAZ ${ }^{1}$, MARÍA DE LA LUZ AYALA-MADRIGAL ${ }^{2}$, MELVA GUTIÉRREZ-ANGULO ${ }^{3}$, \\ AURA ERAZO VALLE-SOLIS ${ }^{4}$, LUIS MIGUEL LINARES-GONZÁLEZ ${ }^{1}$, ROBERTO GONZÁLEZ-GUZMÁN ${ }^{1}$, \\ DAVID CRUZ-GUILLÉN ${ }^{1}$, ANA LILIA CEDEÑO-GARCIDUEÑAS ${ }^{1}$, \\ PATRICIA CANTO ${ }^{5}$ and LUZ BERENICE LÓPEZ-HERNÁNDEZ ${ }^{4}$
}

\author{
${ }^{1}$ National Institute of Rehabilitation, México City; ${ }^{2}$ Institute of Human Genetics, UCHS, University of Guadalajara, Wet Saw, \\ Guadalajara; ${ }^{3}$ Department of Clinics, UCALTOS, University of Guadalajara, Tepatitlán, Jalisco; \\ ${ }^{4}$ National Medical Centre '20th November,' Institute for Social Security of State Workers; \\ ${ }^{5}$ Obesity Research Unit, Faculty of Medicine, National Autonomous University of Mexico, México City, México
}

Received April 8, 2014; Accepted December 17, 2014

DOI: $10.3892 / 01.2015 .2894$

\begin{abstract}
The Asn118Asn (rs11615) variant in the ERCC1 gene, and the Lys751Gln (rs13181) and Asp312Asn (rs1799793) variants in the ERCC2 gene have been associated with the development of varied types of cancer. The aim of the present study was to test for any association between the ERCC1 and ERCC2 gene variants and three different types of cancer in Mexican-mestizo patients. Patients and their respective controls were formed into three groups: The osteosarcoma group, with 28 patients and 97 controls; the colorectal group, with 108 patients and 119 controls; and the breast cancer group, with 71 patients and 74 controls. Genotyping was performed using TaqMan probes and quantitative polymerase chain reaction. Allele and genotype frequencies were compared using a $\chi^{2}$ test. Only one SNP (rs1799793) was found to be associated with breast cancer. This is the first study analyzing the SNPs in ERCC1 and ERCC2 genes and the susceptibility to cancer in Mexican-mestizo patients with osteosarcoma, and colorectal and breast cancer.
\end{abstract}

\section{Introduction}

Excision repair cross-complimentary group 1 (ERCC1) and group 2 (ERCC2) are involved in DNA repair bringing stability and integrity to the genome (1). The ERCC1 and ERCC2 genes are part of the nucleotide excision repair pathway, which is usually indicated to be involved with repair adducts, oxidative DNA damage, cross links, alkylating damage and thymidine dimers $(2,3)$. Therefore, the presence of single nucleotide

Correspondence to: Mr. Benjamín Gómez-Díaz, Division of Cellular and Molecular Morphology, National Institute of Rehabilitation, 289 Carriageway Mexico Xochimilco, Mexico City 14389, Mexico

E-mail: bgodiaz@gmail.com

Key words: ERCC1, ERCC2, cancer, Mexican-mestizos polymorphisms (SNPs) in each gene has been associated with the development of varying types of cancer, depending on the exposure of specific environmental risk factors (4-12). In particular, the Asn118Asn (rs11615; c.354G>A) variant in ERCC1 (13), and the Lys751Gln (rs13181; c.2251A $>$ C) and Asp312Asn (rs1799793; c.934C >T) variants in $\operatorname{ERCC2}(11,12,14)$ have been associated with the risk of cancer in a variety of populations. However, the association with the Mexican-mestizo population has not been tested, even though ethnicity may play a crucial role for case-control based studies for genetic susceptibility variants in complex diseases (15). The aim of the present study was to test for an association between the Asn118Asn (ERCC1), Lys751Gln and Asp312Asn (ERCC2) variants, and osteosarcoma and colorectal and breast cancer in Mexican patients.

\section{Patients and methods}

Patient groups. Analyses were conducted for the following groups: The osteosarcoma group, with 28 patients and 97 healthy controls; the colorectal cancer group, with 108 patients and their respective 119 controls; and the breast cancer group, with 71 females diagnosed with breast cancer and 74 controls. All individuals were of Mexican-mestizo ethnicity. Institutional Committees approved the study and informed written consent was obtained from all participants. the institutions that approved the collection of samples were The National Institute of Rehabilitation, Mexico City, for samples of osteosarcoma tissue, The Civil Hospital of Guadalajara, Guadalajara, Jalisco, for samples of colon cancer tissue and The National Medical Center '20 of November', Institute for Social Security and Services for State Workers, Mexico City, Mexico for samples of breast cancer tissue. Patients were recruited between May 2012 and December 2013, from three tertiary-care level hospitals in Mexico (National Institute of Rehabilitation, Mexico City; National Medical Center '20 of November', Institute for Social Security and Services for State Workers, Mexico City; and Civil Hospital of Guadalajara, Jalisco, Mexico). 
Table I. Clinical data of osteosarcoma patients $(n=28)$.

\begin{tabular}{|c|c|}
\hline Clinical data & Value \\
\hline \multicolumn{2}{|c|}{ Age at diagnosis, years } \\
\hline Median & 20.5 \\
\hline Range & $9-68$ \\
\hline \multicolumn{2}{|l|}{ Gender, \% } \\
\hline Female & 42.9 \\
\hline Male & 57.1 \\
\hline \multicolumn{2}{|l|}{ Subtype, \% } \\
\hline Osteoblastic & 57.1 \\
\hline Chondroblastic & 14.3 \\
\hline Other & 28.6 \\
\hline \multicolumn{2}{|l|}{ Tumor location, $\%$} \\
\hline Femur & 85.7 \\
\hline Tibia & 3.6 \\
\hline Arm & 10.7 \\
\hline \multicolumn{2}{|l|}{ Necrosis, $\%$} \\
\hline Good & 70.0 \\
\hline Poor & 30.0 \\
\hline \multicolumn{2}{|l|}{ Metastasis, $\%$} \\
\hline No & 28.6 \\
\hline At diagnosis & 57.1 \\
\hline At follow-up & 14.3 \\
\hline \multicolumn{2}{|l|}{ Status, $\%$} \\
\hline Alive & 85.7 \\
\hline Succumbed & 14.3 \\
\hline \multicolumn{2}{|l|}{ Relapse, \% } \\
\hline No & 71.4 \\
\hline Yes & 28.6 \\
\hline \multicolumn{2}{|c|}{ Clinical stage at diagnosis, $\%$} \\
\hline 2 & 17.8 \\
\hline 3 & 28.6 \\
\hline 4 & 53.6 \\
\hline \multicolumn{2}{|c|}{ Karnofsky Score, \% } \\
\hline 80 & 21.4 \\
\hline 70 & 28.6 \\
\hline 60 & 35.7 \\
\hline 50 & 3.6 \\
\hline 40 & 10.7 \\
\hline
\end{tabular}

Data collection. Samples of peripheral blood (300 $\mu \mathrm{l})$ were obtained from patients and genomic DNA was isolated by the CTAB-DTAB method that relies on the properties of cationic detergents (16). Genotyping was performed by quantitative polymerase chain reaction (qPCR) using TaqMan probes (hydrolysis probes) and the C_2532959_1_(rs11615/Asn118Asn ERCC1), C_3145033_10 (rs13181/Lys751Gln ERCC2) and C_3145050_10 (rs1799793/Asp312Asn ERCC2) assays (Applied Biosystems, Foster City, CA, USA). qPCR was performed on a LightCycler 480 Instrument II (Roche Diagnostics GmbH, Basel, Switzerland), according to the manufacturer's instructions. Briefly, PCR reactions contained 10-20 ng of DNA, 5.0 $\mu \mathrm{l}$
Table II. Clinical data of colorectal cancer patients $(n=108)$.

\begin{tabular}{ll}
\hline Clinical data & Value
\end{tabular}

Age at diagnosis, years

Median

Range

Gender, \%

Female

Male

Tumor location, \%

Colon

54.1

Rectum

45.9

Table III. Clinical data of breast cancer patients $(n=71)$.

Clinical data Value

Age at diagnosis, years

Median

Range

Pregnancy prior to 30 years of age, $\%$

No

Yes

Breastfeeding more than six months, \%

No

49.5

Yes

Stage, $\%$

1

2

3

HER2(+), \%

No

85.6

Yes

14.4

HER2, human epidermal growth factor receptor 2.

of Maxima Probe qPCR Master Mix (2X; Thermo Fisher Scientific, Austin City, TX, USA), $0.25 \mu 1$ of the primers and probes (10X) and $\mathrm{H}_{2} \mathrm{O}$ to $10 \mu \mathrm{l}$. PCR conditions were $95^{\circ} \mathrm{C}$ for $10 \mathrm{~min}$, 55 cycles of amplification $\left(95^{\circ} \mathrm{C}\right.$ for $30 \mathrm{sec}, 59^{\circ} \mathrm{C}$ for $30 \mathrm{sec}$ and $72^{\circ} \mathrm{C}$ for $40 \mathrm{sec}$ ) and a final extension at $72^{\circ} \mathrm{C}$ for $5 \mathrm{~min}$. Genotype assignment was performed with LightCycler 480 software version 1.5.0 (Roche Diagnostics $\mathrm{GmbH}$ ).

Statistical analysis. Statistical analysis was performed using SPSS software version 18.0 (SPSS, Inc., Chicago, IL, USA) and $\mathrm{P}<0.05$ was considered to indicate a statistically significant difference. The allele and genotype frequencies, and the distribution of genotypes in groups of patients and controls were compared by $\chi^{2}$ or Fisher's exact test. Homozygotes for the most frequent allele were used as reference groups. For measuring the association between genetic polymorphisms and the risk of cancer, odds ratios (ORs) were calculated. Hardy-Weinberg 
Table IV. Genotype frequencies of ERCC1 and ERCC2 polymorphisms of control group (n=97) and osteosarcoma patients (n=28).

\begin{tabular}{|c|c|c|c|c|c|}
\hline Variants & Genotypes & Controls, n (\%) & Patients, n (\%) & OR $(95 \% \mathrm{CI})$ & P-value ${ }^{a}$ \\
\hline \multirow[t]{4}{*}{ ERCC1 rs 11615} & GG & $59(60.8)$ & $16(57.2)$ & 1.00 & \\
\hline & GA & $32(33.0)$ & $9(32.1)$ & $1.04(0.41-2.61)$ & 0.94 \\
\hline & AA & $6(6.2)$ & $3(10.7)$ & $1.84(0.41-8.20)$ & 0.42 \\
\hline & GG/GA & $91(93.8)$ & $25(89.3)$ & $1.16(0.50-2.73)$ & 0.73 \\
\hline \multirow[t]{4}{*}{ ERCC2 rs 13181} & AA & $64(66.0)$ & $21(75.0)$ & 1.00 & \\
\hline & $\mathrm{AC}$ & $31(31.9)$ & $7(25.0)$ & $0.69(0.26-1.79)$ & 0.44 \\
\hline & $\mathrm{CC}$ & $2(2.1)$ & $0(0.0)$ & $0.60(0.03-12.99)$ & 0.42 \\
\hline & $\mathrm{AA} / \mathrm{AC}$ & 95 (97.9) & $28(100.0)$ & $0.65(0.25-1.68)$ & 0.37 \\
\hline \multirow[t]{4}{*}{ ERCC2 rs 1799793} & $\mathrm{CC}$ & $68(70.1)$ & $21(75.0)$ & 1.00 & \\
\hline & $\mathrm{CT}$ & $8(8.3)$ & $3(10.7)$ & $1.21(0.29-4.99)$ & 0.79 \\
\hline & $\mathrm{TT}$ & $21(21.6)$ & $4(14.3)$ & $0.62(0.19-1.99)$ & 0.42 \\
\hline & $\mathrm{CC} / \mathrm{CT}$ & $76(78.4)$ & $24(85.7)$ & $0.78(0.29-2.04)$ & 0.61 \\
\hline
\end{tabular}

${ }^{2} \chi^{2}$ or Fisher's exact test.

Table V. Genotype frequencies of ERCC1 and ERCC2 polymorphisms of control group $(\mathrm{n}=119)$ and colorectal cancer patients (n=108).

\begin{tabular}{|c|c|c|c|c|c|}
\hline Variants & Genotypes & Controls, n (\%) & Patients, n (\%) & OR $(95 \% \mathrm{CI})$ & P-value ${ }^{a}$ \\
\hline \multirow[t]{4}{*}{ ERCC1 rs 11615} & GG & $58(48.7)$ & $46(42.6)$ & 1.00 & \\
\hline & GA & $50(42.1)$ & $47(43.5)$ & $1.18(0.68-2.06)$ & 0.55 \\
\hline & AA & $11(9.2)$ & $15(13.9)$ & $1.72(0.72-4.10)$ & 0.22 \\
\hline & GG/GA & $108(90.8)$ & $93(86.1)$ & $1.28(0.76-2.16)$ & 0.35 \\
\hline \multirow[t]{4}{*}{ ERCC2 rs 13181} & AA & $74(62.2)$ & $69(63.9)$ & 1.00 & \\
\hline & $\mathrm{AC}$ & $39(32.8)$ & $33(30.5)$ & $0.91(0.51-1.60)$ & 0.74 \\
\hline & $\mathrm{CC}$ & $6(5.0)$ & $6(5.6)$ & $1.07(0.33-3.48)$ & 0.91 \\
\hline & $\mathrm{AA} / \mathrm{AC}$ & $113(95.0)$ & $102(94.4)$ & $0.93(0.54-1.59)$ & 0.79 \\
\hline \multirow[t]{4}{*}{ ERCC2 rs 1799793} & $\mathrm{CC}$ & $81(68.1)$ & $74(68.5)$ & 1.00 & \\
\hline & $\mathrm{CT}$ & $23(19.3)$ & $26(24.1)$ & $1.24(0.65-2.35)$ & 0.52 \\
\hline & $\mathrm{TT}$ & $15(12.6)$ & $8(7.4)$ & $0.58(0.23-1.46)$ & 0.24 \\
\hline & $\mathrm{CC} / \mathrm{CT}$ & $104(87.4)$ & $100(92.6)$ & $0.98(0.56-1.71)$ & 0.94 \\
\hline
\end{tabular}

${ }^{a} \chi^{2}$ or Fisher's exact test.

Table VI. Genotype frequencies of ERCC1 and ERCC2 polymorphisms of control group (n=74) and breast cancer patients (n=71).

\begin{tabular}{|c|c|c|c|c|c|}
\hline Variants & Genotypes & Controls, n (\%) & Patients, n (\%) & OR $(95 \% \mathrm{CI})$ & P-value \\
\hline \multirow[t]{4}{*}{ ERCC1 rs 11615} & GG & $40(54.1)$ & $38(53.5)$ & 1.00 & \\
\hline & GA & $27(36.5)$ & $28(39.4)$ & $1.09(0.55-2.18)$ & 0.80 \\
\hline & AA & $7(9.4)$ & $5(7.1)$ & $0.75(0.22-2.57)$ & 0.65 \\
\hline & GG/GA & $67(90.6)$ & $66(92.9)$ & $1.02(0.53-1.96)$ & 0.95 \\
\hline \multirow[t]{4}{*}{ ERCC2 rs 13181} & AA & $45(60.8)$ & $49(69.1)$ & 1.00 & \\
\hline & $\mathrm{AC}$ & $27(36.5)$ & $19(26.7)$ & $0.65(0.32-1.32)$ & 0.23 \\
\hline & $\mathrm{CC}$ & $2(2.7)$ & $3(4.2)$ & $1.38(0.22-8.62)$ & 0.73 \\
\hline & $\mathrm{AA} / \mathrm{AC}$ & $72(97.3)$ & $68(95.8)$ & $0.69(0.35-1.38)$ & 0.30 \\
\hline \multirow[t]{4}{*}{ ERCC2 rs 1799793} & $\mathrm{CC}$ & $54(72.9)$ & $54(76.0)$ & 1.00 & \\
\hline & $\mathrm{CT}$ & $1(1.4)$ & $9(12.7)$ & $9.00(1.10-73.50)$ & $0.01^{\mathrm{b}}$ \\
\hline & $\mathrm{TT}$ & $19(25.7)$ & $8(12.3)$ & $0.42(0.17-1.04)$ & 0.06 \\
\hline & $\mathrm{CC} / \mathrm{CT}$ & $55(74.3)$ & $63(88.7)$ & $0.85(0.40-1.79)$ & 0.67 \\
\hline
\end{tabular}

${ }^{\mathrm{a}} \chi^{2}$ or Fisher's exact test. ${ }^{\mathrm{b}}$ Deviated from Hardy-Weinberg equilibrium. 
equilibrium (HWE) was estimated using the $\chi^{2}$ test (http://ihg.gsf.de/cgi-bin/hw/hwa1.pl; accessed 20/08/2013).

\section{Results}

The clinical data of the patients with osteosarcoma, and colorectal and breast cancer are summarized in Tables I-III. In osteosarcoma, the median age at diagnosis was 20.5 years (range, nine to 68 years); $57.3 \%$ of the patients were males; $57.1 \%$ of cases were osteoblastic subtype, and $14.3 \%$ chondroblastic; $57.1 \%$ presented with metastasis at diagnosis, and $14.3 \%$ at follow-up; $71.4 \%$ exhibited relapse; with $53.6 \%$ patients at clinical stage 4 at diagnosis. In colorectal cancer, the median age at diagnosis was 58 years (range, $25-96$ years); $58 \%$ of the patients were male and for $21.5 \%$ of patients, the tumor was located in the colon. In the case of breast cancer, the median age at diagnosis was 52 years (range, $30-83$ years); $74.2 \%$ of the patients were pregnant at $<30$ years of age; $50.5 \%$ of patients breast-fed for more than six months; and the majority of patients (67\%) were of clinical stage 2 at diagnosis. The genotyping call rate was $>90 \%$. The call rate is the success rate for assigning genotypes; this implies that allele discrimination was optimal. Allele and genotype frequencies of Asn118Asn (ERCCI) and rs13181 (ERCC2) were distributed according to the HWE model in each group in all types of cancer $(\mathrm{P}>0.05)$. Nevertheless no association with any particular type of cancer was found for the aforementioned SNPs (Tables IV-VI). Notably, the HWE test for rs1799793 showed that the genotype frequencies deviated from expected values $(\mathrm{P}<0.05)$ and that this SNP was indeed associated with breast cancer [OR, 9.00; 95\% confidence interval (CI), 1.10-73.50; $\mathrm{P}=0.01]$.

\section{Discussion}

$E R C C 1$ and $E R C C 2$ genes participate in DNA repair and therefore, when mutated, may contribute to genome instability. Thus, genetic variants in these genes may be associated with the susceptibility of various types of cancer, such as osteosarcoma, and colorectal and breast cancer. In vitro studies have shown that rs11615 (ERCCl) is linked to reduced mRNA levels and a consequence reduction in protein production (17). By contrast, the rs13181 and rs1799793 SNPs of the ERCC2 gene are associated with a deficient DNA repair capacity $(18,19)$. Nonetheless, studies in different populations should be performed in order to confirm the association of the aforementioned variants and different types of cancer; since ethnicity is a crucial factor that could modify the penetrance of disease-associated genetic variants (20-22). The present data showed a positive association between rs1799793 and breast cancer, and a lack of association between the rest of the studied variants and osteosarcoma, and colorectal and breast cancer in the Mexican patients. This SNP has been studied in different populations and deviation from HWE has been observed in at least three populations (23-25). Thus it could be possible that this SNP, which is associated with cancer risk and may have a deleterious effect on survival and is a reason for a population to deviate from the expected frequencies of the HWE model. Although more and larger studies are required to confirm this association in different populations, to the best of our knowledge, the present study is the first attempt to analyze the genetic variants of $E R C C 1$ and $E R C C 2$ genes in Mexican-mestizo patients with osteosarcoma, and colorectal and breast cancer.

\section{Acknowledgements}

This study was supported by a CONACYT grant (SALUD 2011-C01-162100). The authors would like to thank Miss. Roxana Bautista and Miss. Raquel Becerril for providing technical assistance.

\section{References}

1. Wood RD, Mitchell M, Sgouros J and Lindahl T: Human DNA repair genes. Science 291: 1284-1289, 2001.

2. De Silva IU, McHugh PJ, Clingen PH and Hartley JA: Defining the roles of nucleotide excision repair and recombination in the repair of DNA interstrand cross-links in mammalian cells. Mol Cell Biol 20: 7980-7990, 2000

3. Chen ZP, Malapetsa A, McQuillan A, et al: Evidence for nucleotide excision repair as a modifying factor of O6-methylguanine-DNA methyltransferase-mediated innate chloroethylnitrosourea resistance in human tumor cell lines. Mol Pharmacol 52: 815-820, 1997

4. Goode EL, Ulrich CM and Potter JD: Polymorphisms in DNA repair genes and associations with cancer risk. Cancer Epidemiol Biomarkers Prev 11: 1513-1530, 2002.

5. Fontana L, Bosviel R, Delort L, et al: DNA repair gene ERCC2, $\mathrm{XPC}, \mathrm{XRCC} 1, \mathrm{XRCC} 3$ polymorphisms and associations with bladder cancer risk in a french cohort. Anticancer Res 28: 1853-1856, 2008.

6. Huang MY, Fang WY, Lee SC, Cheng TL, Wang JY and Lin SR: ERCC2 2251A $>$ C genetic polymorphism was highly correlated with early relapse in high-risk stage II and stage III colorectal cancer patients: a preliminary study. BMC Cancer 8: 50, 2008.

7. Li J, Jin W, Chen Y, Di G, Wu J and Shao ZM: Genetic polymorphisms in the DNA repair enzyme ERCC2 and breast tumour risk in a Chinese population. J Int Med Res 36: 479-488, 2008.

8. Bernard-Gallon D, Bosviel R, Delort L, et al: DNA repair gene ERCC2 polymorphisms and associations with breast and ovarian cancer risk. Mol Cancer 7: 36, 2008.

9. Yao L, Qiu LX, Yu L, et al: The association between ERCC2 Asp312Asn polymorphism and breast cancer risk: a meta-analysis involving 22,766 subjects. Breast Cancer Res Treat 123: 227-231, 2010.

10. Yang Z, Fang X, Pei X and Li H: Polymorphisms in the ERCC1 and $\mathrm{XPF}$ genes and risk of breast cancer in a Chinese population. Genet Test Mol Biomarkers 17: 700-706, 2013.

11. Tan X, Wang Y, Shi L, et al: Polymorphism of ERCC2 Asp312Asn with lung cancer risk: evidence from 20,101 subjects. Genet Test Mol Biomarkers 18: 50-56, 2014.

12. Wen F, Zhao Z, Liu C, et al: A pooled analysis of the ERCC2 Asp312Asn polymorphism and esophageal cancer susceptibility. Tumour Biol 35: 2959-2965 2014.

13. Deng Q, Sheng L, Su D, et al: Genetic polymorphisms in ATM, ERCC1, APE1 and iASPP genes and lung cancer risk in a population of southeast china. Med Oncol 28: 667-672, 2011.

14. Lin H, Lin D and Zheng C: Association of XPD Lys751Gln polymorphism with head and neck cancer susceptibility: evidence from 11,443 subjects. Diagn Pathol 9: 15, 2014.

15. Zhang L, Wang J, Xu L, et al: Nucleotide excision repair gene ERCC1 polymorphisms contribute to cancer susceptibility: a meta-analysis. Mutagenesis 27: 67-76, 2012.

16. Gustincich S, Manfioletti G, Del Sal G, Schneider C and Carninci P: A fast method for high-quality genomic DNA extraction from whole human blood. Biotechniques 11: 298-300, 302, 1991.

17. Yu JJ, Lee KB, Mu C, et al: Comparison of two human ovarian carcinoma cell lines (A2780/CP70 and MCAS) that are equally resistant to platinum, but differ at codon 118 of the ERCC1 gene. Int J Oncol 16: 555-560, 2000.

18. Lunn RM, Helzlsouer KJ, Parshad R, et al: XPD polymorphisms: effects on DNA repair proficiency. Carcinogenesis 21: 551-555, 2000.

19. Duell EJ, Wiencke JK, Cheng TJ, et al: Polymorphisms in the DNA repair genes XRCC1 and ERCC 2 and biomarkers of DNA damage in human blood mononuclear cells. Carcinogenesis 21: 965-971, 2000 
20. Lichtenstein P, Holm NV, Verkasalo PK, et al: Environmental and heritable factors in the causation of cancer - analyses of cohorts of twins from Sweden, Denmark, and Finland. N Engl J Med 343: 78-85, 2000.

21. Yin M, Yan J, Martinez-Balibrea E, et al: ERCC1 and ERCC2 polymorphisms predict clinical outcomes of oxaliplatin-based chemotherapies in gastric and colorectal cancer: a systemic review and meta-analysis. Clin Cancer Res 17: 1632-1640, 2011.

22. Adeyemo A and Rotimi C: Genetic variants associated with complex human diseases show wide variation across multiple populations. Public Health Genomics 13: 72-79, 2010.
23. Paszkowska-Szczur K, Scott RJ, Gorski B, et al: Polymorphisms in nucleotide excision repair genes and susceptibility to colorectal cancer in the Polish population. Mol Biol Rep 2014.

24. Gao K, Mu SQ and Wu ZX: Investigation of the effects of single-nucleotide polymorphisms in DNA repair genes on the risk of glioma. Genet Mol Res 13: 1203-1211, 2014.

25. Chu H, Gu D, Xu M, et al: A genetic variant in ERCC2 is associated with gastric cancer prognosis in a Chinese population. Mutagenesis 28: 441-446, 2013. 